\title{
Paraneoplastic Limbic Encephalitis in Hodgkin's Disease
}

\author{
Sanjeev Deodhare, Paul O'Connor, Danny Ghazarian and Juan M. Bilbao
}

\begin{abstract}
Background: Oat cell carcinoma of the lung is the most common cause of paraneoplastic limbic encephalitis. Association with other malignancies, in particular Hodgkin's disease, is very rare. Case Report: This 23-year-old male presented with a six month history of progressive alteration in mental status, which consisted of insomnia, short-term memory loss, depression and cognitive impairment. Gadolinium MRI of the head showed intense bilateral contrast enhancement affecting the medial aspects of the temporal lobes in the region of the amygdala and hippocampus. The brain biopsy showed minimal neuronal loss with intense perivascular lymphocytic cuffing and microglial nodules. Polymerase chain reaction for herpes simplex and cytomegalovirus were negative. With prednisone treatment, the patient's neurologic status stabilized but did not improve. Four months later, he presented with left axillary lymphadenopathy. Lymph node biopsy was diagnostic of Hodgkin's disease. During the chemotherapy, his lymphadenopathy subsided and his neurologic and mental status improved. When seen last after completion of his chemotherapy, one year after presentation, he had resumed normal social activities and was enrolled in a university language course. Conclusion: This is the first reported case in the English literature of a biopsy proven paraneoplastic limbic encephalitis associated with Hodgkin's disease. Hodgkin's disease should be thought of as a possible cause of paraneoplastic limbic encephalitis in the appropriate clinical setting.
\end{abstract}

\begin{abstract}
RÉSUMÉ: Encéphalite limbique paranéoplasique dans la maladie de Hodgkin. Introduction: L'épithélioma à petites cellules des bronches est la cause la plus fréquente d'encéphalite paranéoplasique du système limbique. L'association avec d'autres néoplasies, particulièrement la maladie de Hodgkin, est très rare. Histoire de cas: Il s'agit d'un jeune homme de 23 ans qui s'est présenté avec une histoire d'altération progressive de son état mental sur une période de six mois, une perte de la mémoire immédiate, de la dépression et un déficit cognitif. L'IRM au gadolinium de la tête a montré un rehaussement intense, bilatéral, du contraste affectant les aspects médians des lobes temporaux dans la région de l'amygdale et de l'hippocampe. La biopsie du cerveau a montré une perte neuronale minime avec manchon lymphocytaire périvasculaire intense et nodules microgliaux. L'amplification par PCR pour détecter le virus de l'herpès simplex et le cytomégalovirus se sont avérées négatives. Sous prednisone, l'état neurologique du patient s'est stabilisé mais ne s'est pas amélioré. Quatre mois plus tard, il a présenté des adénopathies axillaires gauches. Un diagnostic de maladie de Hodgkin a été posé sur la biopsie ganglionnaire. Pendant la chimiothérapie, sa lymphadénopathie a disparu et son état mental s'est amélioré. Lors de sa dernière visite, après sa chimiothérapie, soit un an après sa première consultation, il avait repris ses activités sociales normales et était inscrit à l'université à un cours de langue.
\end{abstract}

Can. J. Neurol. Sci. 1996; 23: 138-140

Paraneoplastic limbic encephalitis (PLE) is most commonly associated with small cell carcinoma of the lung.' This case report is of a 23-year-old male who initially presented with limbic encephalitis; many possible etiologic factors including viral infection and neoplasms were considered in the differential diagnosis. Later in the course of his disease he developed nodular sclerosing Hodgkin's disease. This is an unusual manifestation of Hodgkin's disease, and it should be thought of as a possible cause of PLE in the appropriate clinical setting.

\section{CASE Report}

A 23-year-old man presented with a six month history of progressive alteration in mental status that consisted of insomnia, short term memory loss, behavioral disinhibition, depression, confusion and cognitive impairment. Prior to admission he had one witnessed generalized seizure. The patient's medical and family histories were not contributory.

General physical examination was normal. On neurological examination he was drowsy but able to co-operate. His speech was soft and normal. His mood was sad and his affect restricted, flat and detached. His memory for recent events was very poor, and he recalled none out of three items after two minutes. He had no idea of the date or his location.

From the Departments of Pathology (S.D., D.G.), Neurology (P.O.) and Neuropathology (J.M.B.), St. Michael's Hospital, Toronto.

RECEIVED JULY 26, 1995. ACCEPTED IN FINAL FORM NOVEMBER 20, 1995.

Reprint requests to: Dr. S. Deodhare, Department of Pathology, St. Michael's Hospital, 30 Bond Street, Toronto, Ontario, Canada M5B IW8 
However, memory for remote events was preserved. Cranial nerve examination, muscle tone and co-ordination were normal. Tendon reflexes were symmetrical and both plantar responses were extensor. There were no sensory or cerebellar signs noted.

The EEG revealed nonspecific slowing without clear epileptiform activity. Cerebrospinal fluid (CSF) examination was normal. Gadolinium MRI of the head showed intense bilateral contrast enhancement affecting the medial aspects of the temporal lobes in the regions of amygdala and hippocampus. The lateral aspects of the temporal lobes were unaffected. (Figure A). These clinical and radiographic findings were consistent with encephalitis, and the chronic form of herpes simplex encephalitis and paraneoplastic limbic encephalitis (PLE) were in the differential diagnosis.

A right temporal open brain biopsy showed intense perivascular, lymphocytic cuffing, neuronophagia, microglial nodules, chronic inflammatory cells in the leptomeninges and minimal neuronal loss (Figure B). The lymphocytes were of the T-helper cell phenotype on immunoperoxidase stains. IgG deposition was not demonstrated in the hippocampus. Hemorrhagic necrotic lesions described in herpetic encephalitis were not seen. Polymerase chain reaction (PCR) for herpes simplex and cytomegalovirus were negative. With prednisone treatment the patient's neurologic status stabilized but did not improve. A full work-up with CT scan of the abdomen and chest showed mediastinal, para-aortic and peripancreatic lymphadenopathy. Laparotomy and mediastinoscopic biopsy of the nodes revealed reactive lymphadenopathy. The patient was continued on tapering doses of prednisone over the next several weeks.

His mental status showed continuing severe impairment of recent memory. Four months later he presented with left axillary lymphadenopathy. The lymph node biopsy was diagnostic of Hodgkin's disease, nodular sclerosing subtype with the presence of collagenous fibrosis and Reed-Sternberg cells. The Reed-Sternberg cells reacted positively for CDI5 (LeuM). The bone marrow biopsy showed no evidence of Hodgkin's disease. He was started on six courses of ABVD chemotherapy for stage III Hodgkin's disease. He tolerated the chemotherapy well. During the chemotherapy his lymphadenopathy subsided and his neurologic and mental status improved. When seen last at the completion of his chemotherapy one year after presentation, his short-term memory had strikingly improved, with recall of three out of three objects after five minutes and orientation in all three spheres. He had resumed normal social activities and was enrolled in a university language course.

\section{Discussion}

The clinical picture and radiographic and pathologic findings were compatible with limbic encephalitis in our patient. CT scans and MRI usually appear normal in limbic encephalitis; ${ }^{2}$ however, contrast enhancement in the medial temporal lobes, as seen in this case, has been reported. ${ }^{3}$ The features indicative of viral etiology were not evident on the brain biopsy. The symptoms of limbic encephalitis preceded the clinical detection of lymphadenopathy. The initial laparotomy and mediastinoscopic lymph node biopsy was negative, and this is attributed either to a sampling error or to the effects of steroid therapy. The biopsy proven diagnosis of Hodgkin's disease with the improvement of neurologic symptoms after management of Hodgkin's disease are characteristic of paraneoplastic limbic encephalitis (PLE).

The pathogenesis of paraneoplastic neurologic syndromes, including limbic encephalitis is largely unknown. The inflammatory and degenerative changes in the limbic grey matter resemble those found in viral encephalitis. ${ }^{4}$ However, no viral particles have so far been identified. ${ }^{5}$ Herpes simplex was postulated as a cause of carcinomatous encephalitis in a patient with treated carcinoma of the uterus. ${ }^{6}$ However, this appears to have been a co-incidental herpetic encephalitis rather than paraneoplastic syndrome. The most likely current explanation of paraneoplastic neurologic syndromes is that they are autoimmune disorders, in which the body produces an immune attack on antigens expressed by the portions of the nervous system, and by the underlying neoplasm. ${ }^{5}$ The support for the role of humoral immunity comes from the identification of high titers of anti-Purkinje cell antibody (anti-Yo) and complement fixing polyclonal IgG, antineuronal antibody, (anti-Hu) in the serum and CSF from patients with paraneoplastic neurologic syndromes. ${ }^{7.8}$ In an autopsy study of patients who died of anti-Huassociated paraneoplastic encephalomyelitis, deposits of anti-Hu

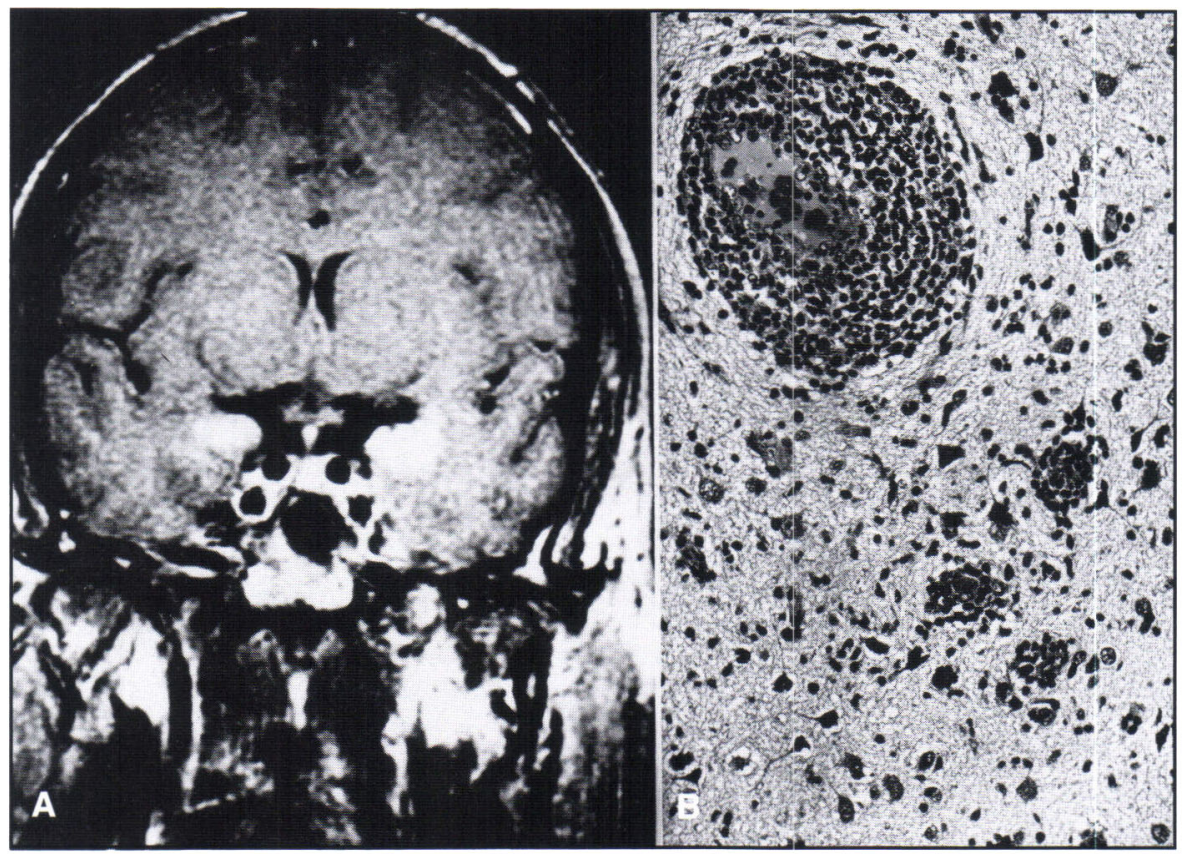

Figure: A) Tl weighted coronal image with contrast enhancement in both hippocampi. B) Intense lymphocytic perivascular infiltrate which extends into the neuropil (H/E $x$ 400). 
antibody were identified in the tumor and in the area of the nervous system that roughly correlated with neurologic symptoms. ${ }^{9}$ Though these clinical studies support the role of humoral immunity, similar neurologic disorders have not been produced in experimental animals, which were injected with human IgG systemically or intrathecally. ${ }^{10,11}$ Intrathecal synthesis of antibodies as seen in humans ${ }^{12,13}$ has not been demonstrated in experimental animals. ${ }^{5}$ A cell-mediated immune attack has been suggested in paraneoplastic ganglionitis and encephalitis. ${ }^{4}$ Similar to this study, ${ }^{4}$ our case also showed predominance of T-lymphocytes. More investigation of the role of T-cells in paraneoplastic syndromes is necessary to further understand the pathogenesis. The more likely explanation of PLE in our case is that the disorder is neither exclusively $\mathrm{T}$ or $\mathrm{B}$ cell mediated, but that $\mathrm{T}$-cells along with an as yet uncharacterized anti-neuronal antibody in Hodgkin's disease, might have played a role in the pathogenesis. The T-lymphocytes on biopsy may be associated with immunopathogenesis, but may not be primarily responsible for it, especially since patients with Hodgkin's disease have defect in cell mediated immunity. ${ }^{14}$

In the literature, paraneoplastic cerebellar degeneration (PCD) is the most commonly reported paraneoplastic neurologic condition associated with Hodgkin's disease. ${ }^{15}$ Hammack et al. ${ }^{15}$ have reported 21 patients with Hodgkin's disease and have reviewed 26 other cases reported. Among the cases of PCD, Hodgkin's disease is the third most common malignancy after lung and ovarian cancers. ${ }^{15}$ Other paraneoplastic neurologic conditions in association with Hodgkin's disease are paraneoplastic myelopathy, ${ }^{16,17}$ Stiff-man syndrome, ${ }^{18}$ acute paraneoplastic sensory ganglionitis, ${ }^{19}$ and limbic encephalitis. ${ }^{20,21}$

Neuronal loss and lymphocytic infiltrate is seen in both $\mathrm{PCD}^{22}$ and PLE. ${ }^{3,9}$ Purkinje cell loss is prominent in $\mathrm{PCD}^{22}$ while the pathologic changes are usually restricted to the limbic and insular cortex in PLE. ${ }^{2}$ Lymphocytic infiltrate in PCD is usually found in the leptomeninges and in the surrounding white matter but not in the Purkinje cell layer. ${ }^{3}$ In contrast, perivascular and parenchymal lymphoid infiltrate is associated with neuronal loss in PLE. ${ }^{3,9}$

Two case reports of memory loss in Hodgkin's disease were identified in our literature search. ${ }^{20,21}$ This association has been reported as Ophelia syndrome. ${ }^{20,21}$ One of the cases had a similar presentation to our case, where the neurologic symptoms preceded the diagnosis of Hodgkin's disease. ${ }^{20}$ The Hodgkin's disease was of nodular sclerosing subtype in both this case and in the one of the previously reported cases. ${ }^{21}$ However, in both the previous case reports there was no biopsy proven diagnosis of limbic encephalitis. ${ }^{20,21}$ In all the three cases, successful treatment of Hodgkin's disease proved to be effective against memory loss and emotional disturbance. ${ }^{20.21}$ Minimal cellular destruction with functional rather than structural damage of the neurons has been suggested as a possible cause for spontaneous or therapy induced remission of neurologic symptoms. ${ }^{5}$ It is of interest that our patient showed minimal neuronal loss. This is the first reported case, in the English literature, of a biopsy proven paraneoplastic limbic encephalitis associated with Hodgkin's disease.

\section{ACKNOWLEDGEMENT}

The authors thank Ms. Betty Hébert and Ms. May Wong for their excellent clerical support in the preparation of this manuscript.

\section{REFERENCES}

1. Bakheit AMO, Kennedy PGE, Behan PO. Paraneoplastic limbic encephalitis: clinico-pathological correlations. J Neurol Neurosurg Psychiatry 1990; 53: 1084-1088.

2. Posner JB. Paraneoplastic syndromes involving the nervous system. In: Aminoff MJ, ed. Neurology and General Medicine. Churchill Livingstone, 1995: 401-420.

3. Dalmau J, Graus F, Rosenblum MK, Posner JB. Anti-Hu-associated paraneoplastic encephalomyelitis/sensory neuronopathy. A clinical study of 71 patients. Medicine 1992; 71(2): 59-72.

4. Panegyres PK, Reading MC, Esiri MM. The inflammatory reaction of paraneoplastic ganglionitis and encephalitis: an immunohistochemistry study. J Neurol 1993; 240: 93-97.

5. Posner JB, Dalmau J. Clinical enigmas of paraneoplastic neurologic disorders. Clin Neurol Neurosurg 1995; 97: 61-70.

6. Dayan AD, Bhahi I, Gostling JVT. Encephalitis due to herpes simplex in a patient with treated carcinoma of the uterus. Neurology 1967; 17: 609-613.

7. Greenlee JE, Brashear HR. Antibodies to cerebellar Purkinje cells in patients with paraneoplastic cerebellar degeneration and ovarian carcinoma. Ann Neurol 1983; 14: 609-613.

8. Anderson NE, Rosenblum MK, Graus F, Wiley RG, Posner JB. Autoantibodies in paraneoplastic syndromes associated with small-cell lung cancer. Neurology 1988; 38: 1391-1398.

9. Dalmau J, Furneaux HM, Rosenblum MK, Graus F, Posner JB. Detection of the anti-Hu antibody in specific regions of the nervous system and tumor from patients with paraneoplastic encephalomyelitis/sensory neuronopathy. Neurology 1991; 41: $1757-1764$

10. Graus F, Illa I, Agusti M, et al. Effect of intraventricular injection of anti-Purkinje cell antibody (anti-Yo) in a guinea pig model. $\mathrm{J}$ Neurol Sci 1991; 106: 82-87.

11. Sillevis-Smitt PAE, Manley GT, Posner JB. High titer antibodies but no disease in mice immunized with the paraneoplastic antigen HuD. Neurology 1994; 44 (2 Suppl.): 378.

12. Furneaux HM, Reich L, Posner JB. Autoantibody synthesis in the central nervous system of patients with paraneoplastic syndromes. Neurology 1990; 40: 1085-1091.

13. Graus F, Segurado OG, Tolosa E. Selective concentration of antiPurkinje cell antibody in the CSF of two patients with paraneoplastic cerebellar degeneration. Acta Neurol Scand 1988; 78: 210-213.

14. Engleman EG, Benike CJ, Hoppe RT, Kaplan HS, Berberich FR. Autologous mixed reaction in patients with Hodgkin's disease: evidence for a T-cell defect. J Clin Invest 1980; 66: 149-158.

15. Hammack J, Kotanides H, Rosenblum MK, Posner JB. Paraneoplastic cerebellar degeneration. II. Clinical and immunologic findings in 21 patients with Hodgkin's disease. Neurology 1992; 42(10): 1938-1943.

16. Dansey RD, Hammond-Tooke GD, Lai K, Bezwoda WR. Subacute myelopathy: an unusual paraneoplastic complication of Hodgkin's disease. Med Pediatr Oncol 1988; 16(4): 284-286.

17. Hughes M, Ahern V, Kefford R, Boyages J. Paraneoplastic myelopathy at diagnosis in a patient with pathologic stage $1 \mathrm{~A}$ Hodgkin disease. Cancer 1992; 70(6): 1598-1600.

18. Ferrari P, Federico M, Grimaldi LM, Silingardi V. Stiff-man syndrome in a patient with Hodgkin's disease. An unusual paraneoplastic syndrome. Haematologica 1990; 75(6): 570-572.

19. Case records of the Massachusetts General Hospital. Weekly clinicopathological exercises. Case 8-1990. A 45-year-old woman with Hodgkin's disease and a neurologic disorder. N Engl J Med 1990; 322(8): 531-543.

20. Carr 1. The Ophelia syndrome: memory loss in Hodgkin's disease. Lancet 1982; 1: 844-845.

21. Peliegler G, Posan E, Glaub D, Telek B, Rak K. Hodgkin's disease and memory loss: another case of the Ophelia syndrome. $\mathrm{Br} \mathrm{J}$ Haematol 1990; 74: 232.

22. Peterson K, Rosenblum MK, Kotanides H, Posner JB. Paraneoplastic cerebellar degeneration. I. A clinical analysis of 59 anti-Yo antibody-positive patients. Neurology 1992; 42: 1931-1937. 